\title{
Knowledge Management dan Peran Strategic Partner SDM: Pengaruhnya Terhadap Perencanaan Strategik dan Kinerja Organisasi (Studi pada Rumah Sakit di Bali)
}

\author{
Desak Ketut Sintaasih ${ }^{1}$ \\ Umar Nimran, Made Sudarma, dan Surachman ${ }^{2}$ \\ ${ }^{1}$ Fakultas Ekonomi, Universitas Udayana \\ ${ }^{2}$ Fakultas Ekonomi dan Bisnis, Universitas Brawijaya \\ E-mail: made@fe.unibraw.ac.id
}

\begin{abstract}
The purpose of this study is to examine, test, and evaluate the influence of the knowledge management and the role of human resources (HR) as a strategic partner in the strategic planning and organizational performance. The study conducted in public hospitals and the private sectors in the region of Bali Province, with the respondent is the head of the hospital in upper and middle levels. At each hospital is given three respondents representing organizations and the unit of analysis is the organization. The data collected directly from respondents using research instruments. Techniques of analysis used partial least square (PLS). The result proves the knowledge management and the role of HR as a strategic partner to improve the accuracy of strategic planning, and strategic planning can improve organizational performance. Knowledge management is also shown to increase the role of HR as strategic partner. Knowledge management does not directly effect the performance of organization, but it proved that the strategic planning mediate the influence of knowledge management on organizational performance. This suggests that knowledge management is not a direct determinant of organizational performance, but its existence becomes an important input of the strategic planning process in an effort to improve organizational performance. The role of HR as a strategic partner also not directly affects the performance of organization, and strategic planning proved to mediate the role of perfect pair strategic HR relationship with organizational performance. This illustrates that the involvement of HR executive as a strategic partner is not direct determinant of organizational performance, but the strategic role of a source of organizational capabilities to conduct strategic planning, in an effort to improve organizational performance. Based on these results, it means that strategic planning is based on the knowledge management and HR role as a strategic partner can be a strategic capabilities, are valuable, rare, inimitable and non substitutable. These capabilities can become the core competencies of the organizations to improve or enhance the performance, which is a source of competitive advantage of the organization in a changing business environment rapidly.
\end{abstract}

Keywords: knowledge management, HR role as strategic partner, strategic planning, organizational performance

\section{PENDAHULUAN}

Ekonomi global dan dunia bisnis dewasa ini sedang berubah dengan cepat dan kompleks, sehingga memicu timbulnya berbagai masalah dalam perusahaan. Dalam perubahan demikian, jaringan inovatif serta gerakan knowledge ekonomi global menambah momentum, sehingga perusahaan-perusahaan menyadari bahwa, persaingan dan metode pengelolaan perusahaan secara strategik berbasis informasi di abad sebelumnya berubah secara fundamental menuju ke knowledge-based, dalam mana kolaborasi strategik menjadi penting sebagai mindset dan praktek strategi bersaing (Leibold et al., 2005).Tekanan persaingan menuntut organisasi harus lebih proaktif dan selalu memikirkan cara-cara beradaptasi dan mengatasi lingkungan yang selalu berubah. Organisasi atau perusahaan dituntut harus memiliki kemampuan mendeteksi kencenderungan perubahan lingkungan dan mampu mengambil keputusan dengan cepat.

Rumah Sakit (RS), sebagai industri jasa kesehatan tidak dapat terhindar dari perubahan tersebut. Perubahan lingkungan yang begitu kompleks, membawa perubahan pandangan stakeholder RS. dan selanjutnya berdampak pada perubahan paradigma dalam pelayanan jasa Rumah Sakit (RS) di Indonesia (Assauri, 2004). RS di Bali yang terus berkembang, baik dalam jumlah maupun kapasitas, tidak luput dari perubahan lingkungan tersebut. Intensitas persaingan semakin meningkat dengan semakin banyaknya RS baru beroperasi khususnya RS swasta. Bahkan RS yang baru dibangun belakangan ini mengklaim sebagai RS berstandar internasional. Peningkatan trend pembangunan RS kelas atas ini, dipicu oleh 
masuknya investor asing, perkembangan populasi kelas menengah atas, membaiknya tingkat pendapatan per-kapita, dan semakin kritisnya masyarakat dalam menjaga kesehatan dan memilih tempat untuk berobat (Azhary, 2009).

Dalam ketidakpastian dan perubahan lingkungan yang demikian cepat, kelangsungan hidup jangka panjang organisasi sangat tergantung pada respon manajemen terhadap tantangan internal dan eksternal (Athiyaman \& Robertson (1995). Dalam hal ini pengelolaan RS memerlukan sistem manajemen yang mampu mengantisipasi perubahan lingkungan yang demikian dinamis. Para pimpinan RS penting meningkatkan kapabilitasnya dalam memutuskan arah pengembangan RS yang lebih adaptif dan inovatif untuk bisa bertahan hidup dalam kondisi lingkungan yang terus bergejolak.

Perencanaan strategik memungkinkan perusahaan untuk mengantisipasi kondisi yang selalu berubahubah (Taylor, 1997; Jauch \& Glueck, 2004) dan menyediakan peta perjalanan dan arah yang dituju serta cara mencapainya (Shapiro, 2009). Perusahaan yang terlibat dalam perencanaan strategik cenderung lebih berkembang di tengah persaingan yang berat dibandingkan yang tidak (Athiyaman \& Robertson, 1995). Perencanaan strategik merupakan perangkat manajemen penting yang dapat membantu organisasi dalam melakukan tugasnya dengan lebih baik. memfasilitasi pengembangan strategi dan implementasi, serta organisasi menjadi lebih sensitif terhadap kebutuhan pelanggan dan pasar (Bonn \& Christodoulou, 1996; Obeng \& Ugboro 2008). Perencanaan strategik (strategic planning) vital bagi organisasi dalam mempertahankan kelangsungan hidupnya (Robbins \& Coulter, 2007; Jauch \& Glueck, 2004; Wheleen \& Hunger, 2004). Baldrige National Quality Program (2008), menetapkan strategic planning sebagai salah satu komponen dari sistem untuk mencapai kinerja unggul.Perencanaan strategik terbukti berpengaruh nyata terhadap kinerja organisasi (Phillips, 1996; Brews \& Purohit, 2007; Rudd et al., 2008).

Para pimpinan RS mengakui bahwa perencanaan strategik merupakan perangkat manajemen penting, namun, perencanaan strategik ini masih menjadi masalah karena berbagai kendala yang dihadapi untuk dapat menyusunnya dengan baik dan tepat. Kendala mendasar menyangkut sumber daya manusia (SDM) dan kendala data/informasi yang sangat menentukan kualitas dan ketepatan rencana strategik (renstra). Adanya berbagai kendala tersebut membuat perencanaan strategik belum optimal sebagai perangkat manajemen penting yang sangat dibutuhkan dalam menghadapi perubahan lingkungan yang berubah demikian cepat.
Faktor sukses kunci penerapan perencanaan strategik adalah proses formulasi strategi yang sistematis, pelaksanaan atau implementasi strategi yang efektif, dan pengendalian serta tindak lanjut dari implementasi (Brenes, et al. 2008). Aliran informasi dan komunikasi adalah kritikal untuk keseluruhan integrasi dan keefektivan perencanaan strategik (Ocasio \& Joseph, 2008). Menurut pandangan berbasis sumber daya, the resource based view of the firm (RBV), sumber daya yang dimiliki perusahaan dapat menjadi sumber yang memungkinkan untuk memperkirakan dan mengimplementasikan strategi yang dapat meningkatkan efisiensi dan efektivitas perusahaan (Barney, 1991). Sumber daya dan kapabilitas perusahaan merupakan prinsip dasar strategi dan faktor penentu profitabilitas perusahaan (Grant, 1997; Collis \& Montgomery,1998). Semakin besar laju perubahan lingkungan eksternal, pencarian dasar strategi jangka panjang dari sumber daya dan kappabilitas internal lebih diperlukan dari pada fokus pasar eksternal.

Berkaitan dengan peran sumber daya dalam menciptakan value, telah terjadi pergeseran paradigma, bahwa intangible asset lebih penting dari pada sumber daya tangible (Allanson, 2009; Galbreath, 2008) dalam pengambilan keputusan strategik (Pehrsson, 2008). Dari aset intangible, knowledge diakui secara luas sebagai aset organisasi paling penting untuk menciptakan value dan keunggulan kompetitif berkelanjutan (Wiig, 1997; Koenig, 1998; Nonaka, 2006; Teece, 2000; Choi et al., 2008; Yang, et al. 2009). Knowledge organisasi terbukti berperan sebagai input kunci bagi proses perumusan strategi manufaktur, mengarahkan pengembangan kapabilitas menciptakan nilai produk (Paiva et al., 2008). Penggunaan marketing knowledge perusahaan cabang berdampak positif pada pengembangan strategik Multi National Corporation (Holm \& Sharma, 2006).

Knowledge begitu strategis bagi organisasi, sehingga knowledge management telah dilakukan dengan sangat sukses oleh banyak organisasi terkemuka (Wiig, 1997). Knowledge management merupakan serangkaian proses mengubah data dan informasi menjadi pengetahuan bermanfaat untuk berbagai kepentingan organisasi (Serrat, 2009; Barclay \& Murray; 2009). Proses ini meliputi penciptaan, akuisisi, penyimpanan, berbagi, dan penggunakan pengetahuan (Koenig, 1998; Bose, 2003; Award \& Ghaziri, 2004). Bentuk dan kemampuan organisasi dalam mengelola pengetahuan (knowledge management) sangat mempengaruhi kualitas pengetahuan yang dihasilkan dan pada akhirnya kualitas tindakan ataupun keputusan dari penggunaan knowledge tersebut. Beberapa kajian 
empirik telah membuktikan bahwa knowledge management berpengaruh signifikan pada kinerja organisasi (Choi et al., 2008; Yang et al., 2009), kinerja inovasi (Liao \& Wu, 2010) dan keunggulan kompetitif (Johannessen \& Olsen, 2003; Chuang, 2004; Masa \& Testa, 2009). Knowledge management juga terbukti berpengaruh signifikan pada strategi pengembangan produk baru dan kinerja pengembangan produk baru (Liu et al., 2005).

Bose (2003) mengkaji suatu sistem aplikasi untuk organisasi perawatan kesehatan, yang mana karyanya menunjukkan bahwa integrasi kapabilitas knowledge management, infrastruktur teknis, dan arsitektur pendukung keputusan membentuk sistem manajemen perawatan kesehatan yang membantu pengambilan keputusan klinis dan administrasi. Huang (2009), juga mengkaji suatu model sistem aplikasi menggunakan The Analytic Hierarchy Process (AHP) Method, menegaskan bahwa sistem berbasis knowledge (knowledge-based systemKBS) dapat menjadi alat perencanaan strategik, merencanakan atau menetapkan strategi berdasarkan informasi pengambilan keputusan. Demikian pula Abidi (2001) dalam rancangan model sistem yang disebutnya Strategic Healthcare DecisionSupport Services (SHDS) menunjukkan suatu bentuk struktur-info beroientasi KM, suatu pendekatan baru perpaduan sinergi antara pengadaan pengetahuan (Data Mining-DM) dan teknik operasionalisasi pengetahuan $(\mathrm{KM})$, yang ditujukan mempengaruhi pengambilan keputusan strategis, perencanaan dan manajemen perusahaan perawatan kesehatan. SHDS dapat memberikan wawasan, rekomendasi, prediksi, dan analisis untuk membantu manajer, pembuat kebijakan dan analis kesehatan membuat keputusan strategis atau memprediksi kemungkinan masa depan.

Penelitian-penelitian sebelumnya telah menyoroti pentingnya knowledge management untuk inovasi, kinerja, keunggulan kompetitif, dan keputusan strategik, namun kajian knowledge management dihubungkan dengan perencanaan strategik kurang jelas terungkap. Di samping itu kajian knowledge management pada industri jasa kesehatan juga kurang mendapat perhatian peneliti-peneliti sebelumnya. Penelitian ini mencoba mengisi kekurangan tersebut dengan meneliti lebih lanjut pengaruh knowledge management pada perencanaan strategik. Knowledge management sebagai sumber daya penting dikaji pengaruhnya pada perencanaan strategik organisasi jasa kesehatan (Rumah Sakit).

Sumber daya knowledge management sangat erat hubungannya dengan sumber daya manusia (SDM), sehingga perencanaan strategik dapat efektif mencapai kinerja organisasi juga sangat ditentukan oleh kapabilitas SDM yang akan menyusun dan merealisasikan rencana strategik yang ditetapkan. Keberhasilan proses manajemen strategik sebagian besar tergantung pada tingkat mana fungsi Manajemen SDM dilibatkan (Noe et al., 2006). Setiap komponen proses perencanaan strategik, yaitu formulasi, implementasi da evaluasi strategi, akan melibatan isu bisnis berkaitan dengan orang (people-related business issue), karena itu, fungsi Manajemen SDM perlu dilibatkan pada tiap-tiap komponen tersebut. Eksekutif SDM dipandang sebagai strategic partner dengan para eksekutif lainnya dan terlibat secara aktif dalam proses pengambilan keputusan strategik (Ulrich, 1997). Peran SDM sebagai mitra strategik (strategic partner) memfokuskn pada aktivitas mencocokan praktek dan strategi SDM dengan strategi perusahaan. Dalam memainkan peran ini, eksekutif SDM bekerja untuk menjadi mitra strategik, membantu meyakinkan keberhasilan strategi perusahaan. Dengan peran ini eksekutif SDM meningkatkan kapabilitas organisasi dalam menyusun dan menjalankan strategi. Peran strategik SDM menjadi penting dan dapat berkontribusi signifikan dalam perencanaan strategik (Ulrich, 1997; Noe et al., 2006).

Walaupun terjadi perubahan pemahaman peran eksekutif SDM dari peran tradisional yang lebih banyak berperan administratif (people issues) menjadi peran SDM strategik (people related business) dalam menciptakan value, kajian-kajian berkaitan dengan peran strategik SDM dalam keseluruhan proses perencanaan strategik masih terbatas diteliti dan dikaji secara empirik. Chen \& Huang (2009), menguji pengaruh mediasi kapabilitas knowledge management antara praktek SDM strategik dan kinerja inovasi. Praktek SDM strategik pada kajian tersebut lebih mengarah pada peran SDM sebagai administrative expert. Akmal (2006) telah meneliti konsep Ulrich, dan hasil penelitiannya menunjukkan bahwa peran SDM sebagai strategic partner berpengaruh signifykan pada kinerja organisasi, namun penelitian ini nampak belum mengkaitkan peran SDM sebagai strategic partner dengan perencanaan strategik. Penelitian ini mencoba menjembatani kesenjangan ini dengan menganalisis peran SDM sebagai strategic partner dalam perencanaan strategik organisasi RS.

Dari seluruh rangkaian paparan di atas, pertanyaan penelitian ini adalah "bagaimana pengaruh knowledge management dan peran strategic partner SDM pada perencanaan strategik dan kinerja organisasi'"?

Rumusan masalah: 1) Apakah knowledge management dan peran strategic partner SDM ber- 
pengaruh terhadap perencanaan strategik?; 2) Apakah perencanaan strategik berpengaruh terhadap kinerja organisasi ?; 3) Apakah knowledge management dan peran strategic partner SDM berpengaruh langsung terhadap kinerja organisasi ?; 4) Apakah knowledge management berpengaruh terhadap peran strategic partner SDM?; 5) Apakah perencanaan strategik memediasi pengaruh knowledge management terhadap kinerja organisasi? 5) Apakah perencanaan strategik memediasi pengaruh peran strategic partner SDM terhadap kinerja organisasi?

\section{KERANGKA KONPSETUAL DAN HIPOTESIS}

Berdasarkan fenomena, telaah teori dan kajiankajian empirik yang dipaparkan di atas, maka digambarkan kerangka konseptual penelitian ini seperti pada Gambar 1.

Kerangka konseptual tersebut menggambarkan sumber daya intangible dan kapabilitas berupa knowledge management dan peran strategic partner SDM dapat berpengaruh terhadap perencanaan strategik dan selanjutnya berpengaruh pada kinerja organisasi. Knowledge management dan peran strategic partner SDM bisa berkontribusi langsung pada kinerja organisasi. Perencanaan strategik dapat memediasi hubungan antara knowledge management dengan kinerja organisasi. Perencanaan strategik juga bisa memediasi hubungan antara peran strategic partner SDM dengan kinerja organisasi.

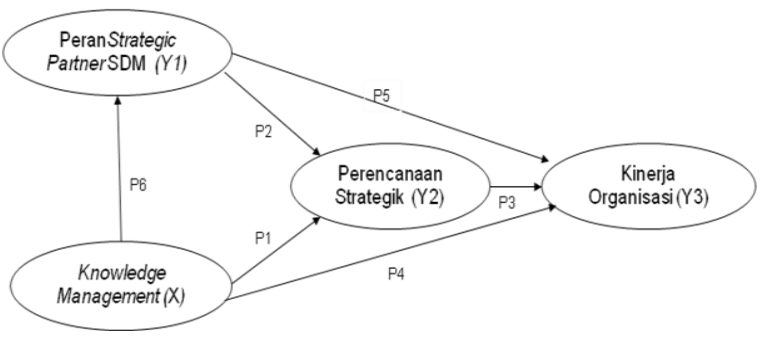

Gambar 1. Kerangka Konseptual Penelitian

\section{Hipotesis Penelitian}

Berdasarkan pada kerangka konseptual penelitian, maka hipotesis penelitian dapat dirumuskan sebagai berikut:

Hipotesis 1: Semakin baik knowledge management, maka akan semakin tepat perencanaan strategik.

Hipotesis 2: Semakin baik Peran strategic partner SDM, maka akan semakin tepat perencanaan strategik.

Hipotesis 3: Semakin tepat perencanaan strategik, maka akan semakin meningkat kinerja organisasi.
Hipotesis 4: Semakin baik knowledge management, maka akan semakin meningkat kinerja organisasi

Hipotesis 5: Semakin baik peran strategic partner SDM, maka akan semakin meningkat kinerja organisasi.

Hipotesis 6: Semakin baik knowledge management maka akan semakin baik peran strategic partner SDM.

Hipotesis 7: Perencanaan strategik akan memediasi pengaruh knowledge management terhadap kinerja organisasi.

Hipotesis 8: Perencanaan strategik akan memediasi pengaruh peran strategic partner SDM terhadap kinerja organisasi.

\section{METODE PENELITIAN}

\section{Populasi, Sampel dan Responden Penelitian}

Penelitian ini dilakukan pada Rumah Sakit (RS) pemerintah dan swasta di Provinsi Bali. Dalam penelitian ini tidak dilakukan sampling, jadi seluruh populasi (42 RS) dijadikan obyek penelitian. Responden penelitian adalah pimpinan RS level atas (top management) dan menengah (middle management), meliputi: Direktur, wakil direktur dan Kepala Bidang Bagian. Pada setiap RS ditetapkan 3 responden yang mewakili organisasi dan unit analisis adalah organisasi.

\section{Variabel Penelitian dan Pengukurannya}

Variabel-variabel dalam penelitian ini dapat diidentifikasi sebagai variabel eksogen yaitu Knowledge Management (X) dan variabel endogen meliputi: Peran Strategic Partner SDM (Y1), Perencanaan Strategik (Y2) dan Kinerja Organisasi (Y3). Setiap variabel ini merupakan variabel laten (unobserved) yang diukur dari beberapa indikator. Tiap-tiap indikator terdiri atas beberapa item yang lebih lanjut dijabarkan dalam butir-butir pertanyaan dalam instrumen penelitian sebagai variabel terobservasi.

\section{Knowledge Management $(\mathrm{X})$}

Variabel Knowledge management (X) yang dimaksud dalam penelitian ini adalah kapabilitas/ kemampuan Rumah Sakit (RS) dalam memperoleh (acquisition), mendokumentasikan (storing), berbagi (sharing), dan menggunakan (application), pengetahuan yang berkaitan dengan peluang dan tantangan lingkungan eksternal yang dihadapi RS dan pengetahuan tentang sumber daya internal (kekuatan atau 
kelemahan) RS. Variabel ini diukur dari 4 indikator, yaitu: Knowledge acquisition (XI); Knowledge sharing (X2); Knowledge storing (X3; dan Knowledge application (X4).

\section{Peran SDM sebagai Strategic Partner (Y1)}

Variabel Peran strategic partner SDM (Y1) dalam penelitian ini adalah peran strategis Bidang/ Bagian yang mengatur SDM di dalam organisasi RS. Konstruk ini diukur dengan 10 indikator sebagai berikut: Peran Bidang/Bagian SDM dalam membantu organisasi mencapai tujuan (Y1.1); Partisipasi Bidang/Bagian SDM dalam proses mendefinisikan strategi organisasi (Y1.2); Peran Bidang/Bagian SDM dalam meyakinkan strategi SDM selaras dengan strategi organisasi (Y1.3); Kemampuan Bidang/ Bagian SDM dalam membantu strategi terjadi (Y1.4); Pandangan terhadap Bidang/Bagian SDM sebagai partner organisasi (Y1.5); Penyediaan waktu oleh Bidang/Bagian SDM untuk isu-isu strategis (Y1.6); Partisipasi Bidang/Bagian SDM dalam perencanaan organisasi (Y1.7); Peran Bidang/Bagian SDM dalam mesejajarkan strategi SDM dan strategi organisasi (Y1.8); Peran Bidang/Bagian SDM dalam mengembangkan proses dan program berkaitan dengan strategi SDM untuk menjalankan strategi organisasi (Y1.9); dan Kepercayaan kepada Bidang/Bagian SDM dalam membantu mencapai tujuan strategis RS (Y1.10).

\section{Perencanaan Strategik (Y2)}

Variabel Perencanaan strategik (Y2) dalam penelitian adalah proses penyusunan rencana strategik Rumah Sakit, meliputi 3 tahap, yaitu: tahap formulasi strategi, implementasi strategi dan tahap evaluasi strategi, mengacu pada (David, 2005, Thompson, et al. 2006, Pearce \& Robinson, 2006, Rudd, et al, 2008). Tahapan tersebut sekaligus menjadi indikator pengukuran variabel perencanaan strategik dan dapat diidentifikasi sebagai berikut: Formulasi strategi (Y2.1); Implementasi strategi (Y2.2); dan Evaluasi strategi (Y2.3).

\section{Kinerja Organisasi (Y3)}

Variabel Kinerja organisasi (Y3) dalam penelitian ini adalah hasil akhir yang diperoleh organisasi RS atas aktivitas yang telah dilakukan. Dalam penelitian ini kinerja RS diukur dari perspektif berimbang antara internal-eksternal dan finansial-non finansial, mengacu pada konsep balance scorecard (Norton \& Kaplan, 1996). Kinerja organisasi diukur dari empat perspektif atau indikator, yaitu: Perspektif finansial (Y3.1), diukur dari pertumbuhan penjualan, pertumbuhan pendapatan bersih, pertumbuhan aset, dan hasil yang diperoleh pemilik modal dalam tiga tahun terakhir. Perspektif pelanggan (Y3.2), diukur dari kepuasan pelanggan, yaitu tingkat komplain pasien/pelanggan atas lima dimensi kualitas layanan RS meliputi: aspek tangible, reliability responseveness, assurance dan empathy, mengacu pada SERVQUAL dari Parasuraman et al. (1991). Perspektif proses operasional (Y3.3), dalam penelitian ini menitik beratkan pada penyampaian pelayanan kepada pasien secara efisien, konsisten, dan tepat waktu, yang merupakan karakteristik dari kualitas pelayanan. Dalam operasionalnya, kualitas pelayanan RS diukur dari tingkat upaya inovasi dan kreativitas RS terhadap lima dimensi SERVQUAL yaitu: aspek tangible, reliability, responsiveness, assurance dan empathy. Perspektif pembelajaran dan pertumbuhan (Y3.4), diukur dengan kepuasan karyawan dan dalam operasionalnya diukur dari tingkat keluhan karyawan atas dimensi kepuasan kerja (Robbins, 2006).

Dalam pengukuran data digunakan skala Likert dengan interval penilaian dari skor 1 (sangat tidak setuju) sampai dengan skor 5 (sangat setuju). Pengukuran masing-masing indikator variabel yang terdiri atas item, menggunakan nilai rata-rata item. Unit analisis adalah institusi, dan tiap RS diwakili 3 responden. Nilai skor item tiap-tiap institusi RS dihitung nilai rata-rata, dengan formula: Rata-rata skor $=\Sigma$ skor item: 3

\section{Pengumpulan Data}

Data dikumpulkan dari sumber primer dan sekunder. Data sekunder dikumpulkan dari beberapa pusat data seperti Badan Pusat Statistik (BPS), Dinas Kesehatan Provinsi Bali, dan publikasi-publikasi lain yang relevan. Data primer dikumpulkan langsung dari responden dengan menggunakan instrumen penelitian dan wawancara. Instrumen penelitian, terlebih dahulu dilakukan tryout untuk menguji validitas dan reliabilitasnya. Hasil pengujian validitas membuktikan bahwa semua indikator variabel dan butir pertanyaan dalam instrumen penelitian adalah valid ( $\mathrm{r}$ $>0,30$ ). Instrumen penelitian juga bersifat reliabel, mengingat keempat variabel mempunyai reliabilitas yang dapat diterima (Alpha Cronbach > 0.60).

\section{Teknik Analisis Data}

Teknik analisis yang digunakan adalah SEM berbasis variance yang terkenal disebut Partial Least Square (PLS). Berdasarkan kerangka konseptual penelitian yang dibangun atas dasar teori dan kajiankajian penelitian terdahulu, maka dapat digambarkan model empirik penelitian ini, seperti Gambar 2. 


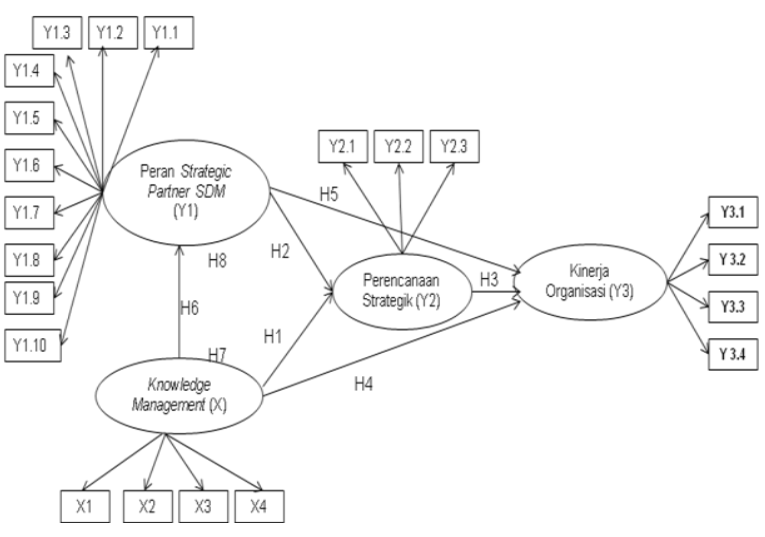

Gambar 2. Model Empirik

Dalam penelitian ini semua variabel merupakan variabel laten dengan indikator reflektif sehingga evaluasi model pengukuran (outer model) menggunakan convergent dan discriminant validity dari indikator dan composite realibility untuk blok indikator. Goodness of Fit model diukur menggunakan Rsquare predictive relevance untuk model struktural (inner model). $Q$-Square predictive relevance untuk model struktural (inner model), mengukur seberapa baik nilai observasi dihasilkan oleh model dan juga estimasi parameternya. Besaran $\mathrm{Q}^{2}$ dengan rentang 0 $<\mathrm{Q}^{2}<1$, semakin mendekati nilai 1 berarti model semakin baik

\section{HASIL PENELITIAN DAN PEMBAHASAN}

\section{Evaluasi Model Pengukuran (Outer Model)}

Dari hasil pengujian outer model dapat diketahui outer loading setiap indikator dan nilai square root of average variance extracted (AVE) setiap variabel laten dibandingkan dengan korelasi antar variabel laten lainnya dalam model (Lampiran). Dengan memperhatikan informasi pada Lampiran, terbukti bahwa nilai outer loading semua indikator di atas 0,5 dan T-Stastistic di atas 1,96, sehingga indikator-indikator tiap variabel merupakan indikator yang valid sebagai pengukur variabel. Ke empat variable, Knowledge Management (X), Peran Strategic Partner SDM (Y1), Perencanaan Strategik (Y2) dan Kinerja Organisasi (Y3), memiliki nilai AVE di atas 0,5 , dan nilai akar AVE untuk setiap variabel lebih tinggi dibandingkan dengan korelasi antar variabel. Dengan demikian model penelitian memiliki discriminant validity yang cukup. Nilai Composite Reliability juga memenuhi angka di atas 0,70, sehingga dapat disimpulkan bahwa blok indikator reliable mengukur konstruk.

\section{Evaluasi Model Struktural (Inner Model)}

Dalam model struktural ini terdapat tiga variabel dependen, yaitu peran strategic partner SDM (Y1), perencanaan strategik (Y2) dan kinerja organisasi (Y3). Berdasarkan nilai koefisien determinasi $\left(\mathrm{R}^{2}\right)$ masing-masing model struktural (Lampiran), terbukti $Q^{2}=0.93$, nilai yang mendekati angka 1 . Ini berarti goodness of fit model struktural sangat baik. Dengan kata lain dapat diinterpretasikan bahwa informasi yang terkandung dalam data 93\% dapat dijelaskan oleh model, sisanya 7\% dijelaskan oleh error dan .variabel lain yang belum terdapat dalam model.

\section{Hasil Pengujian Hipotesis}

Hasil uji validasi koefisien path pada setiap jalur untuk pengaruh langsung disajikan pada Tabel 4. Dari informasi pada Tabel 4 dapat dijelaskan hasil pengujian hipotesis sebagai berikut.

Tabel 1. Hasil Pengujian Hipotesis Pengaruh Langsung antar Variabel

\begin{tabular}{|c|c|c|c|c|}
\hline $\mathrm{No}$ & Hubungan antar Variabel & $\begin{array}{c}\text { Koefisien } \\
\text { Jalur } \\
\text { (Standardize) }\end{array}$ & $\begin{array}{c}\mathrm{T}- \\
\text { Statistic }\end{array}$ & $\begin{array}{c}\text { Keteranga } \\
\mathrm{n}\end{array}$ \\
\hline 1 & $\begin{array}{l}\text { Knowledge Management } \\
(\mathrm{X}) \rightarrow \text { Perencanaan } \\
\text { Strategik (Y2) }\end{array}$ & 0.402 & 2.299 & Signifikan \\
\hline 2 & $\begin{array}{l}\text { Peran Strategic Partner } \\
\text { SDM }(\mathrm{Y} 1) \rightarrow \text { Perencanaan } \\
\text { Strategik }(\mathrm{Y} 2)\end{array}$ & 0.409 & 3.310 & Signifikan \\
\hline 3 & $\begin{array}{l}\text { Perencanaan Strategik (Y2) } \\
\rightarrow \text { Kinerja Organisasi (Y3) }\end{array}$ & 0.604 & 1.983 & Signifikan \\
\hline 4 & $\begin{array}{l}\text { Knowledge Management } \\
(\mathrm{X}) \rightarrow \text { Kinerja Organisasi } \\
\text { (Y3) }\end{array}$ & 0.143 & 0.576 & $\begin{array}{l}\text { Non } \\
\text { Signifikan }\end{array}$ \\
\hline 5 & $\begin{array}{l}\text { Peran Strategic Partner } \\
\text { SDM (Y1) } \rightarrow \text { Kinerja } \\
\text { Organisasi (Y3) }\end{array}$ & 0.135 & 0.170 & $\begin{array}{l}\text { Non } \\
\text { signifikan }\end{array}$ \\
\hline \multirow[t]{2}{*}{6} & $\begin{array}{l}\text { Knowledge Management } \\
(\mathrm{X}) \rightarrow \text { Peran Strategic } \\
\text { Partner SDM }(\mathrm{Y} 1)\end{array}$ & 0.720 & 10.101 & Signifikan \\
\hline & $\begin{array}{r}\text { Pengujian Perencanaan St } \\
\text { Model tanp }\end{array}$ & $\begin{array}{l}\text { ik sebag } \\
\text { riabel M }\end{array}$ & ariabel I & asi: \\
\hline 7 & $\begin{array}{l}\text { Knowledge Management } \\
\text { (X) } \rightarrow \text { Kinerja Organisasi } \\
\text { (Y3) }\end{array}$ & 0.380 & 2.272 & Signifikan \\
\hline 8 & $\begin{array}{l}\text { Peran Strategic Partner } \\
\text { SDM (Y2) } \rightarrow \text { Kinerja } \\
\text { Organisasi (Y3) }\end{array}$ & 0.236 & 4.363 & signifikan \\
\hline
\end{tabular}

Knowledge management $(\mathrm{X})$ terbukti berpengaruh positif signifikan pada perencanaan strategik (Y2). Hasil ini dapat diartikan, dengan semakin baik knowledge management maka perencanaan strategik juga semakin baik atau semakin tepat. Hipotesis 1 terbukti. 
Peran strategic partner SDM (Y1) juga berpengaruh positif dan signifikan terhadap perencanaan strategik (Y2). Hasil ini memberi bukti bahwa semakin baik atau strategik peran eksekutif SDM dalam organisasi maka perencanaan strategik juga semakin baik atau tepat. Ini berarti hipotesis 2, terbukti. Dari hasil pengujian juga terbukti perencanaan strategik (Y2) berpengaruh positif signifikan terhadap kinerja organisasi (Y3). Temuan ini dapat diartikan dengan semakin baik/tepat perencanaan strategik maka semakin baik atau semakin meningkat pula kinerja organisasi. Dengan demikian, hipotesis 3 terbukti.

Dari hasil pengujian ini ternyata knowledge management $(\mathrm{X})$ berpengaruh positif tetapi tidak signifikan terhadap kinerja organisasi (Y3). Hasil ini memberi indikasi bahwa dengan semakin baik atau buruk knowledge management, maka tidak berpengaruh secara langsung menjadikan kinerja organisasi semakin baik atau buruk. Dengan demikian hipotesis 4, tidak terbukti. Peran Strategic Partner SDM (Y1) juga berpengaruh tidak signifikan terhadap kinerja organisasi (Y3). Pengujian ini menunjukkan dengan semakin strategis atau tidak strategis peran eksekutif SDM ternyata tidak berpengaruh secara langsung menjadikan semakin baik atau buruk kinerja organisasi. Dari analisis ini ternyata hipotesis 5 juga tidak terbukti. Knowledge Management (X) berpengaruh positif signifikan terhadap Peran strategic partner SDM (Y1). Dari hasil uji ini dapat dinyatakan semakin baik knowledge management maka peran strategic partner SDM juga semakin baik. Hipotesis 6 terbukti.

Dengan memperhatikan hasil pengujian yang disajikan pada Tabel 4, maka dapat diuraikan hasil pengujian variabel mediasi sebagai berikut. Pengaruh knowledge management terhadap perencanaan strategik adalah signifikan; pengaruh perencanaan strategik terhadap kinerja organisasi adalah signifikan; pengaruh langsung knowledge management terhadap kinerja organisasi dengan melibatkan perencanaan strategik (variabel mediasi) adalah nonsignifikan dengan koefisien jalur 0,135 ; sementara pengaruh langsung knowledge management terhadap kinerja organisasi tanpa melibatkan variabel perencanaan strategik adalah signifikan dengan koefisien jalur 0.380 . Dari hasil pengujian ini menunjukkan perencanaan strategik adalah sebagai variabel mediasi sempurna (complete mediation) dalam pengaruh knowledge management terhadap kinerja organisasi. Dengan demikian hipotesis 7, terbukti.

Pengujian variabel mediasi pada hubungan peran strategic partner SDM dengan kinerja organisasi dapat dijelaskan seperti berikut. Peran strategic partner SDM berpengaruh signifikan pada perencanaan strategik; pengaruh perencanaan strategik terhadap kinerja organisasi adalah signifikan; pengaruh langsung peran strategic partner SDM terhadap kinerja organisasi dengan melibatkan variabel perencanaan strategik adalah nonsignifikan, dengan koefisien jalur 0,143; dan pengaruh langsung peran strategic partner SDM terhadap kinerja organisasi tanpa melibatkan variabel perencanaan strategik adalah signifikan, dengan koefisien jalur 0.236 . Dengan demikian, dari pengujian ini dapat disimpulkan bahwa perencanaan strategik adalah sebagai variabel mediasi sempurna (complete mediation) pada hubungan strategic partner SDM dengan kinerja organisasi. Hasil ini memberi arti dengan semakin strategis peran eksekuitf SDM maka kinerja organisasi akan semakin baik atau meningkat melalui perencanaan strategik yang baik atau tepat. Dengan demikian hipotesis 8, bahwa perencanaan strategik memediasi pengaruh peran strategic partner SDM terhadap kinerja organisasi, terbukti.

\section{PEMBAHASAN}

\section{Pengaruh Knowledge Management terhadap Perencanaan Strategik}

Knowledge management terbukti berpengaruh positif signifikan terhadap perencanaan strategik. Hasil ini memberi indikasi bahwa pelaksanaan knowledge management yang baik menjadikan perencanaan juga dapat dilakukan dengan baik. Semakin baik knowledge management semakin baik kapabilitas organisasi dalam melakukan perencanaan strategik. Temuan penelitian ini dapat diartikan bahwa upaya-upaya dalam memperoleh, berbagi, mendokumentasikan, dan menggunakan pengetahuan yang berkaitan dengan kondisi eksternal dan internal yang dilakukan dengan baik, maka identifikasi peluang dan tantangan eksternal dan kekuatan serta kelemahan internal yang dimiliki organisasi juga dapat dilaksanakan dengan baik. Dengan pengetahuan yang dikreasi melalui proses knowledge management tersebut terbukti dapat meningkatkan kemampuan organisasi dalam melakukan formulasi, implementasi dan evaluasi strategi, sehingga perencanaan strategik menjadi baik atau tepat.

Dalam perolehan knowledge, organisasi mendapatkan dari sumber eksternal dan internal organisasi. Knowlegde dari sumber eksternal meliputi informasi dari publikasi berbagai media cetak dan elektronik, perkembangan kebutuhan masyarakat akan kesehatan, tingkat persaingan, pemasok, pasien/ pengguna, termasuk dari ahli/konsultan. Sementara 
knowledge dari sumber internal, meliputi: pengetahuan pimpinan dan karyawan, pengidentifikasian sumber daya internal organisasi, dan pengetahuan dari rutinitas organisasi. Knowledge tersebut dapat menjadi lebih baik karena secara teratur melaksanakan knowledge sharing, melalui pertemuan formal dan atau informal antar pimpinan, antara pimpinan dan karyawan serta antar unit/bagian di dalam organisasi. Sharing pengetahuan juga dilakukan dengan mendatangkan konsultan manajemen dan berbagi pengetahuan secara on line menggunakan intranet ke seluruh bidang/bagian organisasi. Organisasi juga memiliki kemampuan menyimpan atau mendokumentasikan knowledge dalam media penyimpanan (file elektronik dan, atau buku) dengan rapi dan aman, mengintegrasikan pendokumentasian dengan deskripsi pekerjaan (job description), sehingga knowledge tersebut mudah dan cepat dapat diakses atau dicari kembali dari media penyimpanan. Dengan demikian, organisasi dapat menggunakan knowledge dengan mudah, tepat dan efektif untuk pengambilan keputusan.

Knowledge management terbukti menjadi determinan penting dari perencanaan strategik. Dalam melakukan perencanaan strategik, visi dan misi organisasi dirumuskan dengan jelas, analisis peluang dan tantangan eksternal serta identifikasi kekuatan dan kelemahan internal juga dilakukan dengan cermat. Selanjutnya, penetapan tujuan jangka menengah dengan indikator-indikatornya juga jelas dan terukur sehingga sejumlah alternatif strategi dapat ditetapkan dengan cermat, sehingga pemilihan strategi yang paling cocok bagi organisasi juga dilakukan dengan baik. Perencanaan strategik tidak berhenti sampai pada formulasi strategi. Strategi yang telah dirumuskan dapat dijabarkan lebih lanjut dengan jelas dan terukur dalam implementasinya. Implementasi strategi menyangkut penjabaran tujuan jangka menengah ke dalam tujuan tahunan dengan indiaktor-indikatornya yang jelas dan terukur. Tujuantujuan tersebut menjadi landasan yang baik dalam penetapan program kerja di masing-masing bidang fungsional, penetapan kebijakan operasional (standard operating procedure - SOP), penyusunan struktur organisasi dan standar kompetensi jabatan, sistem informasi, dan sistem imbalan atau reward. Semua aktivitas tersebut dapat dilakukan dengan jelas dan terukur. Perencaanan strategik juga dilengkapi dengan mekanisme pengendalian yang jelas, teratur dan tepat waktu.

Dengan mengacu the resource-based view of the firm, maka proses perencanaan strategik yang didukung dengan knowledge management itu sendiri dapat dipandang sebagai kapabilitas bersaing dan dengan sifatnya yang tidak mudah dipindahkan secara sempurna merupakan competitive advantage organisasi yang diciptakan dari kapabilitas tersebut.

\section{Pengaruh Peran strategic partner SDM terhadap Perencanaan Strategik}

Peran strategic partner SDM berpengaruh positif signifikan terhadap perencanaan strategik. Hasil ini menggambarkan peran strategik eksekutif SDM dalam organisasi berkontribusi nyata pada proses penyusunan rencana strategik. Semakin strategis peran eksekutif SDM semakin baik atau tepat perencanaan strategik. Pengaruh positif terjadi karena eksekutif SDM diposisikan sebagai mitra strategik bersama para eksekutif lainnya dalam organisasi dan terlibat secara aktif dalam proses formulasi, implementasi dan evaluasi strategi.

Seperti telah terungkap dalam penelitian ini, eksekutif SDM memberikan kontribusi pada perencanaan strategik organisasi melalui sepuluh peran strategik, yaitu: berperan dalam membantu organisasi mencapai tujuan, berpartisipasi aktif dalam proses mendefinisikan strategi organisasi, meyakinkan bahwa strategi SDM searah dengan strategi organisasi, membantu strategi organisasi terlaksana dengan efektif, sebagai partner organisasi, menyediakan waktu yang cukup untuk isu-isu strategis, berpartisipasi dalam perencanaan organisasi, menyelaraskan strategi SDM dengan strategi organisasi, mengembangkan proses dan program berkaitan dengan strategi SDM untuk menjalankan strategi organisasi, serta dipercaya dalam membantu mencapai tujuan strategis organisasi.

Temuan penelitian memperkuat konsep Ulrich (1997) dan Noe et al. (2006) yang menyoroti pentingnya peran strategis divisi atau departemen SDM dalam menghadapi tantangan lingkungan. Peran divisi SDM tidak hanya sebagai divisi personalia (fully administrative), tetapi memiliki peran strategis. Divisi SDM memiliki kontribusi dalam menentukan masa depan organisasi melalui orientasi fungsional pada pengembangan, kreativitas, fleksibilitas dan manajemen proaktif. Eksekutif SDM dipandang sebagai mitra strategik dengan para eksekutif lainnya dan terlibat secara aktif dalam proses pengambilan keputusan strategik

\section{Pengaruh Perencanaan Strategik terhadap Kiner- ja Organisasi}

Perencanaan strategik terbukti berpengaruh positif signifikan terhadap kinerja organisasi. Ini menunjukkan bahwa perencanaan strategik yang baik atau tepat berkontribusi nyata dalam meningkatkan 
kinerja organisasi. Semakin baik atau tepat perencanaan strategik, semakin meningkat kinerja organisasi.

Perencanaan strategik yang tepat berdampak positif pada kinerja perspektif finansial, perspektif pelanggan, perspektif proses operasional dan perspektif pembelajaran pertumbuhan. RS di Bali cukup inovatif dan kreatif dalam mengembangkan kualitas layanan, didukung dengan penciptaan lingkungan kerja, sistem pengembangan karier dan sistem reward yang kondusif, sehingga terwujud kepuasan karyawan. Kondisi tersebut berdampak positif pada kepuasan pasien/pelanggan dan selanjutnya mempengaruhi pencapaian kinerja finansial yaitu meningkatnya penjualan/penerimaan, pertumbuhan pendapatan bersih, pertumbuhan aset dan hasil yang diperoleh pemilik modal.

Dengan mengkonfirmasi hasil penelitian ini dengan penelitian-penelitan sebelumnya, diperoleh suatu informasi penting bahwa dalam lingkungan yang berubah demikian cepat, perencanaan dapat menjadi perangkat manajemen yang sangat penting yang membawa organisasi lebih adaftif dan proaktif untuk menopang pencapaian kinerja yang telah ditargetkan.

\section{Pengaruh Knowledge Management terhadap Kinerja Organisasi}

Hasil pengujian menunjukkan knowledge management tidak berpengaruh signifikan terhadap kinerja organisasi. Hasil ini menunjukkan bahwa baik atau buruknya organisasi dalam memperoleh, mendokumentasikan, berbagi dan memanfaatan pengetahuan tentang peluang, tantangan, kekuatan dan kelemahan organisasi (knowledge management), tidak berpengaruh langsung pada peningkatan atau penurunan kinerja organisasi dari aspek finansial, palanggan, proses operasional dan kinerja pembelajaran dan pertumbuhan.

Sebagaimana Serrat (2009) menegaskan, knowledge adalah aset berharga yang membantu pengambilan keputusan. Dalam hal ini, keputusan tentu bisa sifatnya strategik, taktis ataupun operasional, sehingga kebutuhan akan pengetahuan adalah konteksual sesuai tujuannya. Bila pengetahuan ditujukan untuk pengambilan keputusan strategik sebagaimana diteliti dalam penelitian ini, tentu dampak langsungnya adalah pada keputusan strategik. Sementara dampaknya pada kinerja organisasi tidak langsung, tetapi melalui keputusan stratetgik yang diambil.
Pengaruh Peran strategic partner SDM terhadap Kinerja Organisasi

Peran SDM sebagai Strategic Partner terbukti berpengaruh tidak signifikan terhadap kinerja organisasi. Hasil ini memberi bukti bahwa tinggi rendahnya peran eksekutif SDM sebagai Strategic Partner tidak berkontribusi secara nyata pada baik atau buruknya kinerja organisasi. Partisipasi aktif eksekutif SDM sebagai mitra strategik dengan para eksekutif lainnya dan terlibat secara aktif dalam proses pengambilan keputusan strategik ternyata bukan determinan langsung dari kinerja organisasi.

Hasil penelitian ini tidak sejalan dengan penelitian Akmal (2006), yang meneliti pengaruh multi peran manajemen sumber daya manusia (MSDM) terhadap kinerja perusahaan di perusahaan BUMN. Hasil penelitiannya menunjukkan bahwa secara parsial peran SDM sebagai mitra strategik berpengaruh signifikan pada kinerja organisasi. Hasil yang berbeda dengan penelitian ini bisa terjadi karena bila kembali dicermati teori RBV (Barney, 1991) dan pendekatan strategi berbasis sumber daya (Grant, 1997), nampaknya peran SDM sebagai strategic partner adalah merupakan kapabilitas organisasi yang memfasilitasi pengambilan keputusan strategik dalam organisasi. Jadi kapabilitas tersebut bisa tidak berdampak langsung pada kinerja organisasi, tetapi lebih berkontribusi langsung pada keputusan strategik yang diambil.

\section{Pengaruh Knowledge Management terhafap Peran strategic partner SDM}

Knowledge Management berpengaruh positif signifikan terhadap peran Strategic Partner SDM. Keterkaitan ini menggambarkan bahwa dengan knowledge management yang semakin baik menjadikan peran eksekutif SDM sebagai strategic partner menjadi semakin baik. Untuk dapat memainkan peran sebagai mitra strategik dengan baik, eksekutif SDM tentu memerlukan informasi atau pengetahuan yang sesuai pada saat yang tepat terkait dengan peluang, tantangan, kekuatan dan kelemahan organisasi. Dengan adanya aktivitas knowledge acquisition, knowledge sharing, knowledge storing, dan knowledge application yang berjalan dengan baik dalam organisasi, peran tersebut dapat dilakukan dengan baik. Seperti terungkap dalam penelitian ini, knowledge management berkontribusi nyata pada peran SDM sebagai strategic partner. 
Peran Mediasi Perencanaan Strategik pada Hubungan Knowledge Management dengan Kinerja Organisasi.

Hasil pengujian variabel mediasi membuktikan perencanaan strategik memediasi secara sempurna (complete mediation) pengaruh knowledge management terhadap kinerja organisasi. Temuan ini memberi arti, bahwa knowledge management ternyata bukan determinan langsung kinerja organisasi, namun keberadaanya merupakan determinan penting perencanaan strategik untuk menuju perbaikan atau peningkatan kinerja organisasi. Hasil ini mengindikasikan bahwa pengetahuan organisasi tentang kondisi eksternal dan internal yang dikreasi melalui proses knowledge management akan dapat memperbaiki kinerja organisasi melalui penyusunan rencana strategik dengan tahapan formulasi, implementasi dan evaluasi strategi yang tepat. Semakin baik penerapan knowledge management maka semakin baik atau meningkat kinerja organisasi melalui perencanaan strategik yang semakin baik atau tepat.

Organisasi dalam menjaga kelangsungan hidupnya, harus menekankan pelaksanaan knowledge management dan perencanaan strategik sebagai kapabilitas strategik organisasi dalam bersaing. Organisasi harus sepenuhnya memahami pengetahuan tentang kondisi eksternal dan internal dan dengan cermat memanfatkan pengetahuan tersebut dalam merumuskan, mengimplementasikan dan mengevaluasi keputusan-keputusan strategik untuk mencapai target kinerja organisasi yang lebih tinggi. Hasil penelitian ini menunjukkan bahwa knowledge management dan perencanaan strategik adalah fungsi yang berkaitan membentuk kapabilitas organisasi yang berharga dan berimplikasi positif pada kinerja organisasi.

Peran Mediasi Perencanaan Strategik pada Hubungan Peran Strategic Partner SDM dengan Kinerja Organisasi.

Hasil penelitian menunjukkan perencanaan strategik memediasi secara sempurna hubungan peran SDM sebagai strategic partner dengan kinerja organisasi. Hasil ini memberi bukti bahwa dalam organisasi, dimana eksekutif SDM adalah berperan sebagai strategic partner dapat meningkatkan kapabilitas organisasi dalam merumuskan, mengimplementasi dan mengendalikan strategi, dan selanjutkan akan meningkatkan atau memperbaiki kinerja organisasi pada empat aspek, finansial, pelanggan, proses operasional dan pembelajaran pertumbuhan. Peran eksekutif SDM sebagai strategic partner tidak secara langsung meningkatkan kinerja organisasi, akan tetapi melalui partisipasi dan peran aktifnya pada perencanaan strategik organisasi. Dengan demikian, kapabilitas eksekutif SDM dikontribusikan dengan baik dalam seluruh proses penyusunan rencana strategik dan melalui perencanaan strategik tersebut kinerja organisasi dapat diperbaiki.

Dari perspektif RBV (Barney,1991) hasil penelitian ini menunjukkan bahwa peran strategik eksekutif SDM merupakan sumber kapabilitas organisasi untuk menghasilkan perencanaan strategik yang lebih baik atau tepat. Kapabilitas tersebut menjadi kapabilitas berharga dalam mewujudkan kinerja organisasi yang lebih baik yang merupakan sumber keunggulan bersaing.

\section{KESIMPULAN DAN SARAN}

Penerapan knowledge management yang baik mampu meningkatkan ketepatan perencanaan strategik. Hasil ini menunjukkan bahwa, pelaksanaan knowledge acquisition, knowledge sharing, knowledge storing dan knowledge application terbukti dapat meningkatkan kemampuan organisasi dalam mengindentifikasi peluang, tantangan, kekuatan dan kelemahan, sehingga formulasi, implementasi dan evaluasi strategi dapat dilakukan dengan tepat. Peran strategic partner SDM juga dapat meningkatkan kemampuan organisasi dalam melakukan perencanaan strategik. Ini mengindikasikan bahwa divisi/ eksekutif SDM yang terlibat secara aktif sebagai mitra strategik organisasi, dapat meningkatkan ketepatan formulasi, implementasi dan evaluasi atau pengendalian strategi.

Pelaksanaan perencanaan strategik yang baik terbukti mampu meningkatkan kinerja organisasi. Ini menunjukkan bahwa aktivitas formulasi, implementtasi dan evaluasi strategi yang tepat dapat meningkatkan kinerja organisasi, pada aspek finansial, pelanggan (kepuasan pelanggan), proses operasional (kualitas layanan) dan pembelajaran pertumbuhan (kepuasan karyawan). Knowledge management mampu meningkatkan peran strategic partner SDM. Ini mengindikasikan bahwa knowledge acquisition, knowledge sharing, knowledge storing dan knowledge application yang dilaksanakan dengan baik, dapat meningkatkan kapabilitas eksekutif SDM dalam memainkan peran sebagai mitra strategik, membantu organisasi menangani isu-isu strategik.

Penerapan knowledge management terbukti tidak secara langsung dapat meningkatkan kinerja organisasi. Demikian pula peran strategic partner SDM ternyata juga tidak secara langsung mampu meningkatkan kinerja organisasi. Hasil ini menunjukkan bahwa pelaksanaan knowledge acquisition, 
knowledge sharing, knowledge storing dan knowledge application dengan baik, terbukti bukan merupakan determinan langsung untuk perbaikan kinerja organisasi. Demikian pula eksekutif SDM yang terlibat aktif membantu organisasi menangani isu-isu strategik juga tidak secara langsung dapat memperbaiki kinerja organisasi.

Berdasarkan temuan penelitian ini, penerapan knowledge management dapat meningkatkan kinerja organisasi melalui pelaksanaan perencanaan strategik yang baik. Perencanaan strategik memediasi secara sempurna (complete mediation) pengaruh knowledge management terhadap kinerja organisasi. Ini mengindikasikan bahwa pelaksanaan knowledge management yang baik bukan menjadi determinan langsung kinerja organisasi, akan tetapi keberadaannya menjadi input penting sepanjang proses perencanaan strategik, sehingga upaya dalam meningkatkan kinerja organisasi dapat tercapai.

Peran strategic partner SDM ternyata juga tidak secara langsung mampu meningkatkan kinerja organisasi. Terbukti dalam penelitian ini, perencanaan strategik memediasi dengan sempurna (complete mediation) keterkaitan peran strategic partner SDM dengan kinerja organisasi. Hal ini menggambarkan bahwa keterlibatan eksekutif SDM secara aktif sebagai mitra strategik ternyata bukan determinan langsung kinerja organisasi. Namun, peran strategis eksekutif SDM merupakan sumber kapabilitas organisasi di dalam proses perencanaan strategik, dalam upaya organisasi meningkatkan kinerjanya.

Secara keseluruhan dapat dikatakan bahwa perencanaan strategik yang dilandasi dengan knowledge management dan peran strategic partner SDM, dapat merupakan kapabilitas strategik organisasi yang berharga, langka dan tidak dapat ditiru serta disubsitusi. Kapabilitas demikian dapat menjadi kompetensi inti organisasi untuk memperbaiki atau meningkatkan kinerja, yang merupakan sumber keunggulan bersaing organisasi dalam menghadapi lingkungan bisnis yang berubah dengan cepat.

\section{Implikasi Penelitian}

Temuan penting dan menarik dari hasil penelitian ini adalah dibuktikannya, bahwa knowledge management dan peran strategic partner SDM merupakan sumber daya intangible penting organisasi untuk dapat menghasilkan perencanaan strategik yang baik atau tepat. Knowledge management juga terbukti sebagai sumber daya penting bagi eksekutif SDM untuk meningkatkan kapabilitasnya dalam berperan dan berpartipasi aktif memutuskan isu-isu strategik organisasi. Knowledge management dan peran strategic partner SDM terbukti bukan determinan langsung dari kinerja organisasi, namun kontribusinya pada kinerja organisasi adalah melalui perencanaan strategik.

Temuan penelitian dapat mengkonfirmasi the resource-based view of the firm, utamanya pada pendekatan strategi berbasis sumber daya (Barney, 1991; Grant, 1997; Collis \& Montgomery,1998). The resource-based view of the firm menekankan bahwa sumber daya perusahaan (tangible, intangible dan capability), dapat menjadi sumber untuk memperkirakan dan mengimplementasikan strategi, yang dapat meningkatkan efisiensi dan efektivitas perusahaan, serta dapat mendorong pengembangan keunggulan bersaing organisasi. Menurut pandangan ini, sumber daya intangible atau kapabilitas yang berharga, langka dan sulit ditiru adalah sumber keunggulan bersaing berkelanjutan organisasi. Dalam the resource-based strategy (Grant, 1997; Collis \& Montgomery, 1998), yaitu pendekatan strategi berbasis sumber daya, menekankan bahwa sumber daya dan kapabilitas perusahaan berperan sebagai prinsip dasar strategi dan faktor penentu profitabilitas perusahaan. Temuan penelitian ini juga memperkuat konsep Ulrich (1997) dan Noe et al. (2006), terkait dengan perubahan peran divisi SDM, dari divisi personalia (fully administrative) menjadi divisi SDM strategik. Eksekutif SDM berperan sebagai mitra strategik (strategic partner) sejajar dengan manajemen senior lainnya dalam organisasi, dan terlibat secara aktif dalam pengambilan keputusan strategik. Dalam peneltian ini terbukti, bahwa knowledge management dan peran strategic partner SDM merupakan sumber daya intangible berharga dan menjadi sumber kapabilitas organisasi untuk dapat melakukan perencanaan strategik dengan baik, yang sangat dibutuhkan dalam menghadapi perubahan lingkungan yang berubah cepat. Perencanaan strategik yang dilandasi dengan knowledge management dan peran strategic partner SDM dapat merupakan kapabilitas organisasi yang berharga, langka dan sulit ditiru dengan sempurna untuk mewujudkan perbaikan kinerja organisasi yang merupakan sumber keunggulan bersaing.

\section{Saran-saran}

Para pimpinan organisasi, utamanya yang bergerak dalam pelayanan kesehatan (rumah sakit), penting untuk lebih memperhatikan pengelolaan pengetahuan organisasinya, terutama perlu lebih cermat dalam memperoleh pengetahuan tentang faktor lingkungan eksternal dan internal organisasi. Pengetahuan tersebut sangat menentukan kecermatan keputusan strategik yang diambil dalam upaya 
organisasi memperbaiki kinerja, menuju peningkatan daya saing.

Bagi organisasi penting menjadikan knowledge management sebagai bagian dari aktivitas rutin. Para pimpinan organisasi sudah saatnya mesti mengembangkan kebijakan dan mekanisme yang mampu mendorong penerapan knowledge management, yang merupakan kapabilitas organisasi dalam memperoleh (acquisition), mendokumentasikan (storing), berbagi (sharing), dan memanfaatkan (application) pengetahuan. Untuk mendapatkan pengetahuan yang lebih berkualitas dan sesuai dengan berbagai kepentingan organisasi, maka proses knowledge management dapat pula didukung dengan perangkat teknologi informasi seperti intranet ataupun internet, serta budaya knowledge sharing, sehingga proses penciptaan pengetahuan akan lebih cepat dan efektif.

Eksekutif SDM penting diposisikan sebagai mitra strategik, sejajar dengan para eksekutif lainnya dalam organisasi, dan terlibat secara aktif dalam proses formulasi, implementasi dan evaluasi strategi. Peran aktif eksekutif SDM sangat membantu menentukan kecermatan keputusan strategik yang diambil organisasi, yang pada akhirnya berdampak pada perbaikan kinerja dan daya saing.

\section{Keterbatasan Penelitian}

Penelitian ini masih memiliki keterbatasan, terutama berkaitan dengan sampel dan responden penelitian. Peneliti mendatang dapat memperluas wilayah penelitian, misalnya mencakup wilayah Indonesia, sehingga kajian yang lebih mendalam dapat dilakukan dengan membedakan tipe dan status kepemilikan RS. Responden penelitian juga dapat ditentukan secara proporsional sesuai dengan ukuran besar kecilnya organisasi. Dalam pengukuran kinerja organisasi dari perspektif pelanggan, responden penelitian seharusnya juga melibatkan pasien atau pelanggan, sehingga bisa mendapatkan informasi yang lebih obyektif. Penelitian selanjutnya barangkali juga bisa mengaplikasikan kerangka penelitian ini pada sektor bisnis lain.

\section{DAFTAR PUSTAKA}

Abidi, Syed Sibte Raza. 2001. "Knowledge Management in Healthcare: Towards 'KnowledgeDriven' Decision-Support Services", International Journal of Medical Informatics, page: 5-18.

Akmal. 2006. "Pengaruh Peran Manajemen Sumber Daya Manusia Terhadap Kinerja Perusahaan: Persepsikan Manajer Menengah BUMN", Usahawan, XXXV, hal. 17-23.
Allanson, Jodee. 20 Mei 2009. "Intellectual Capital and Knowledge Management: A New Era in Management Thinking?", http://www.usq.edu. au/extrafiles/business/journals/HRMJournal/Jo deeAllanson.pdf.

Assauri, Sofjan. 2004. "Tantangan Pimpinan Rumah Sakit Menghadapi Paradigma Baru", Usahawan, XXXIII, hal. 50-55.

Athiyaman, A. \& R W. Robertson. 1995. "Strategic Planning in Large Tourism Firms: An Empirical Analysis", Tourism Management, page: 199-205.

Awad, Elias M. \& Hasan M. Ghaziri. 2004. Knowledge Management, International Edition, New Jersey: Pearson Education.

Azhary, M. Emil. 2009. "Potret Bisnis Rumah Sakit Indonesia", Economic Review No. 218, Desember.

National Institute of Standards and Technology. 2008. Baldrige National Quality Program. Washington: US Department of Commerce.

Barclay, Rebecca O. \& Philip C. Murray. 17 Januari 2009. "What is Knowledge Management?", http://www.imamu.edu.sa/Scientific_selection s/abstracts/Abstract\%20\%20IT\%20\%203/Wh at\%20Is\%20Knowledge\%20Management.pdf

Barney, Jay B. 1991. "Firm Resource and Sustained Competitive Advantage", Journal of Management, page: 99-120.

Bonn, Ingrid \& Chris Christodoulou. 1996. "From Strategic Planning to Strategic Management", Long Range Planning, page: 543-551.

Bose, Ranjit. 2003. "Knowledge ManagementEnabled Health Care Management Systems: Capabilities, Infrastructure, and DecisionSupport", Expert Systems with Applications, page: $59-71$.

Bornemann, Manfred, Marion Graggober, Erich Hartlieb Bernd Humpl, Philipp Koronakis, Arthur Primus, Karl Ritsch, Herwig Rollett Martin Sammer Josef Tuppinger Reinhard Willfort \& Kurt WOIs. 2 April 2003. "An lllustrated Guide to Knowledge Management", http:// www.wm-forum.org.

Brenes, Esteban R., Mauricio Mena, German E. Molina. 2008. "Key Success Factors for Strategy Implementation in Latin America", Journal of Business research, page: 590-598.

Brews, Peter \& Devavrat Purohit. 2007. "Strategic Planning in Unstable Environments", Long Range Planning, page: 64-83. 
Chen, Chung-Jen \& Jing-Wen Huang. 2009. “Strategic Human Resource Practices and Innovation Performance-The Mediating Role of Knowledge Management Capacity", Journal of Business Research, page: 104-114.

Choi, Byounggu, Simon K. Poon \& Joseph G. Davis. "Effects of Knowledge Management Strategy on Organizational Performance: A Complementarity Theory-Based Approach", The International Journal of management Science, page: $235-251$.

Chuang, Shu-Hui. 2004. "A Resource-Based Perspective on Knowledge Management Capability and Competitive Advantage: An Empirical Investigation", Expert Systems with Application, page: $459-465$.

Collis, David J. \& Cynthia A. Montgomery. 1998. Corporate Strategy - A Resource - Based Approach. Boston: McGraw-Hill.

David, Fred R. 2005. Strategic Management, Concepts and Case, Tenth Edition, New Jersey: Prentice-Hall.

Galbreath, Jeremy. 2005. "Which Resources Matter the Most to Firm Success? An Exploratory Study of Resource-Based Theory", Technovation, page: 979-987.

Ghozali, Imam. 2008. Structural Equation Modeling Metode Alternatif dengan Partial Least Square-PLS, Edisi Kedua, Semarang: Badan Penerbit Universitas Diponogoro.

Grant, Robert M. 1997. Contemporary Strategy analysis Concept, Techniques, and Apllication, Second Edition, Secokusumo, T. (Penerjemah). Analisis Strategi Kontemporer, Konsep, Teknik, dan Aplikasi, Jakarta: Erlangga.

Grant, Robert M. 1997. “The Knowledge-Based View of the Firm: Implications for Management Practice", Long Range Planning, page: 450454.

Hair, Joseph F. JR, Rolph E. Andersen \& William C. Black. 2010. Multivariate Data Analysis, New Jersey: Prentice-Hall.

Harris, Lloyd C. \& Emmanuel Ogbonna. 2006. "Initiating Strategic Planning", Journal of Business Research, page: 100-111.

Holm, Ulf \& D. Deo Sharma. 2006. "Subsidiary Marketing Knowledge and Strategic Development of the Multinational Corporation", Journal of International Management, page: 47-66.
Huang, Hao-Chen, 2009, "Designing a KnowledgeBased System for Strategic Planning: A Balanced Scorecard Perspective", Expert Systems with Applications, page: 209218.

Jauch, Lawrence R. \& William F. Glueck. 2004. Strategic Management and Business Policy. Ninth Edition, New York: McGraw-Hill.

Johannessen, Jon-Arild \& Bjorn Olsen. 2003. "Knowledge Management and Sustainable Competitive Advantages: The Impact of Dynamic Contextual Training", International Journal of Information Management, page: $277-289$.

Kaplan, Robert S. \& David P. Norton. 1996. The Balance Scorecard: Translating Strategy into Action. Boston: Harvard Business School Press.

Koenig, Michael E.D. 1998. "From Intellectual Capital to Knowledge Management: What are They Talking About?", INSPEL, page: 222-233.

Leibold, Marius, Gilbert Probst, \& Michael Gibbert. 2005. Strategic Management in the Knowledge Economy, New Approaches and Business Application, Second Edition, Germany: Publicis Corporate Publishing and Wiley-VCH-Verlag GmbH \& Co KgaA.

Liu, Pang-Lo, Wen-Chin Chen, \& Chih-Hung Tsai. 2005. "An Empirical Study on The Correlation between The Knowledge Management Method and New Product Development Strategy on Product Performance in Taiwan's Industries", Technovation, page: 637-644.

Noe, Raymond A., John R. Hollenbeck, Barry Gerhart \& Patrick M. Wright. 2006. Human Resource Management, Gaining a Competitive Advantage, Fifth Edition, Boston: McGraw-Hill.

Nonaka, Ikujiro. 7 September 2009. “Creating Sustainable Competitive Advantage through Knowledge-Based Management", http://www.opd. go.th/uploads/file/nonaka.pdf.

Obeng, Kofi \& Isaiah Ugboro. 2008. "Effective Strategic Planning in Public Transit Systems", Transportation Research, page: 420-439.

Ocasio, William \& John Joseph. 2008. "Rise and Fall-or Transformation? The Evolution of Strategic Planning at the General Electric Company 1940-2006", Long Range Planning, page: 248-272. 
Paiva, Ely Laureano, Aleda V. Roth, \& Jaime Evaldo Fensterseifer. 2008. "Organizational Knowledge and The Manufacturing Strategy Process: A Resource-Based View Analysis", Journal of Operations Management, page: $115-132$.

Parasuraman, A., Leonard L. Berry, \& Valarie A. Zeithaml. 1991. "Perceived Service Quality as Customer-Based Performance Measure: An Empirical Examination of Organizational Barriers Using as Extended Service Quality Model", Human Resource Management, page: 335-364.

Pearce II, John A. \& Richard B. Robinson. 2007. Strategic Management, Formulation, Implementation and Control, Tenth Edition, New York: McGraw-Hill.

Pehrsson, Anders. 2008. "Strategy Antecedents of Modes of Entry into Foreign Markets", Journal of Business Research, page: 32-140.

Phillips, Paul A. 1996. "Strategic Planning and Business Performance in The Quoted UK Hotel Sector: Results of An Exploratory Study", International Journal and Hospitality Management, page: 347-362.

Porter, Michael E. 1994. Competitive Advantage, Terjemahan, Jakarta: Binarupa Aksara.

Robbins, Stephen P. 2006. Perilaku Organisasi, Edisi Kesepuluh, Terjemahan, Jakarta: Erlangga.

Robbins, Stephen P. \& Mary Coulter. 2007. Management, Eighth Edition, Terjemahan, Jakarta: Indeks.

Rothberg, Helen N., \& G. Scott Erickson. 2005. From Knowledge to Intelligence, Creating Competitive Advantage in the Next Economy. Amsterdam, Noth Holland: Elsevier.

Rudd, John M., Gordon E. Greenley, Amanda T. Beatson \& Ian N. Lings. 2008. "Strategic Planning and Performance: Extending the Debate", Journal of Business Research, page: 99-108.

Solimun. 2008. Memahami Metode Kuantitatif Mutakhir Structural Equation Modeling dan Partial Least Square, Malang: Program Studi Statistika FMIPA Universitas Brawijaya.

Sugiyono. 2009. Metode Penelitian Kuantitatif Kualitatif, Bandung: Penerbit Alfabeta.
Tanabe, Mario, Claudio Felisoni De Angelo \& Nicholas Alexander. 2004. "The Effectiveness of Strategic Planning: Competitiveness in The Brazilian Supermarket Sector", Journal of Retailing and Consumer Services, page: 145-159.

Taylor, Bernard. 1997. "The Return of Strategic Planning-Once More with Feeling", Long Range Planning, page: 334-344.

Teece, David J. 2000. "Strategies for Managing Knowledge Assets: the Roke of Firm Structure and Industrial Context", Long Range Planning, page: $35-54$.

Thompson, Gamble \& Strickland. 2006. Strategy, Winning in the Marketplace, Boston: McGraw-Hill International Edition.

Totanan, Chalarce. 2004. "Peranan Intellectual Capital dalam Penciptaan Nilai untuk Keunggulan Bersaing", Usahawan, hal. 27-31.

Ulrich, Dave. 1997. Human Resource Champions, The Next Agenda for Adding Value and Delivering Results, Boston: Havard Business School Press.

Wheelen, Thomas L. \& J. David Hunger. 2004. Strategic Management, Business Policy, Nineth Edition, New Jersey: Pearson Educational International.

Widajat, Rochmanaji. 2009. Being a Great and Sustainable Hospital, Jakarta: PT Gramedia Pustaka Utama.

Widayana, Lendy. 2005. Knowledge Management Meningkatkan Dara Saing Bisnis, Malang: Banyumedia Publishing.

Wiig, Karl M. 1997. "Integrating Intellectual Capital and Knowledge Management", Long Range Planning, page: 399 - 405.

Yang, Ching-Chiao, Peter B. Marlow, \& Chin-Shan Luc. 2009. "Knowledge Management Enablers in Liner Shipping", Transportation Research, page: 893-903.

Zheng, Wei, Baiyin Yang \& Gary N. McLean. 2009. "Linking Organizational Culture, Structure, Strategy, and Organizational Effectiveness: Mediating Role of Knowledge Management", Journal of Business Research, page: 1-11. 


\section{Lampiran}

Loading Factor Setiap Indikator Variabel Penelitian

\begin{tabular}{|c|c|c|c|}
\hline Variabel & Indikator & Outer Loading & T-Statistic \\
\hline \multirow{4}{*}{$\begin{array}{l}\text { Knowledge } \\
\text { Mangement } \\
\text { (X) }\end{array}$} & Knowledge acquisition (X1) & 0.926 & 38.268 \\
\hline & Knowledge sharing (X2) & 0.803 & 7.774 \\
\hline & Knowledge storing (X3) & 0.910 & 39.345 \\
\hline & Knowledge application (X4) & 0.874 & 15.734 \\
\hline \multirow{10}{*}{$\begin{array}{l}\text { Peran Strategic } \\
\text { Partner SDM } \\
\text { (Y1) }\end{array}$} & $\begin{array}{l}\text { Peran Bidang/Bagian SDM dalam membantu organisasi } \\
\text { mencapai tujuan (Y1.1). }\end{array}$ & 0.851 & 24.867 \\
\hline & $\begin{array}{l}\text { Partisipasi Bidang/Bagian SDM dalam proses } \\
\text { mendefinisikan strategi organisasi (Y1.2). }\end{array}$ & 0.841 & 16.335 \\
\hline & $\begin{array}{l}\text { Peran Bidang/Bagian SDM dalam meyakinkan bahwa } \\
\text { strategi SDM searah dengan strategi organisasi (Y1.3). }\end{array}$ & 0.764 & 22.771 \\
\hline & $\begin{array}{l}\text { Kemampuan Bidang/Bagian SDM dalam membantu } \\
\text { strategi terjadi (Y1.4). }\end{array}$ & 0.936 & 15.338 \\
\hline & $\begin{array}{l}\text { Pandangan terhadap Bidang/Bagian SDM sebagai } \\
\text { partner organisasi (Y1.5). }\end{array}$ & 0.821 & 55.792 \\
\hline & $\begin{array}{l}\text { Penyediaan waktu oleh Bidang/Bagian SDM untuk isu- } \\
\text { isu strategis (Y1.6). }\end{array}$ & 0.890 & 20.335 \\
\hline & $\begin{array}{l}\text { Partisipasi Bidang/Bagian SDM dalam perencanaan } \\
\text { organisasi (Y1.7). }\end{array}$ & 0.875 & 34.532 \\
\hline & $\begin{array}{l}\text { Peran Bidang/Bagian SDM dalam mesejajarkan } \\
\text { strategi SDM dan strategi organisasi (Y1.8). }\end{array}$ & 0.885 & 29.884 \\
\hline & $\begin{array}{l}\text { Peran Bidang/Bagian SDM dalam mengembangkan } \\
\text { proses dan program berkaitan dengan strategi SDM } \\
\text { untuk menjalankan strategi organisasi (Y1.9). }\end{array}$ & 0.893 & 37.788 \\
\hline & $\begin{array}{l}\text { Kepercayaan kepada Bidang/Bagian SDM dalam } \\
\text { membantu mencapai tujuan strategis RS (Y1.10). }\end{array}$ & 0.875 & 26.366 \\
\hline \multirow{3}{*}{$\begin{array}{l}\text { Perencanaan } \\
\text { Strategik (Y2) }\end{array}$} & Formulasi strategi (Y2.1) & 0.950 & 135.135 \\
\hline & Implementasi strategi (Y2.2) & 0.955 & 105.375 \\
\hline & Evaluasi strategi (Y2.3) & 0.870 & 12.645 \\
\hline \multirow{4}{*}{$\begin{array}{l}\text { Kinerja } \\
\text { Organisasi } \\
\text { (Y3) }\end{array}$} & Persepektif finansial (Y3.1) & 0.592 & 6.196 \\
\hline & Perspektif pelanggan (Y3.2) & 0.921 & 34.567 \\
\hline & Perspektif proses operasional (Y3.3) & 0.936 & 45.390 \\
\hline & Perspektif pembelajaran dan pertumbuhan (Y3.4) & 0.883 & 36.426 \\
\hline
\end{tabular}

Nilai AVE, $\sqrt{A V E}$, Korelasi antar Variabel Laten dan Composite Reliability

\begin{tabular}{|c|c|c|c|c|c|c|c|}
\hline \multirow{2}{*}{ Variabel } & \multirow{2}{*}{ AVE } & \multirow{2}{*}{ Akar AVE } & \multicolumn{4}{|c|}{ Korelasi } & \multirow{2}{*}{$\begin{array}{l}\text { Composite } \\
\text { Reliability }\end{array}$} \\
\hline & & & $\mathrm{X}$ & Y1 & $\mathrm{Y} 2$ & $\mathrm{Y3}$ & \\
\hline$X$ & 0.774 & 0.8642 & 1.000 & & & & 0.932 \\
\hline Y1 & 0.747 & 0.8798 & 0.720 & 1.000 & & & 0.967 \\
\hline Y2 & 0.857 & 0.9257 & 0.696 & 0.698 & 1.000 & & 0.947 \\
\hline Y3 & 0.714 & 0.8450 & 0.661 & 0.660 & 0.798 & 1.000 & 0.907 \\
\hline
\end{tabular}

Hasil Pengujian Goodness of Fit

\begin{tabular}{clcl}
\hline Model & Variabel dependen & $\mathrm{R}^{2}$ & $\mathrm{Q}^{2}$ \\
\hline 1 & Peran Strategic Partner SDM (Y1) & 0.518 & $1-\left(1-\mathrm{R}_{1}{ }^{2}\right)\left(1-\mathrm{R}_{2}{ }^{2}\right)(1-$ \\
2 & Perencanaan Strategik (Y2) & 0.566 & $\left.\mathrm{R}_{3}{ }^{2}\right)=0.93013$ \\
3 & Kinerja Organisasi (Y3) & 0.666 & \\
\hline
\end{tabular}

